\title{
A review on phytochemical and pharmacological potentials of Antidesma bunius
}

\begin{abstract}
Antidesma bunius (Family- Euphorbiaceae), also popularly known in the Philippines as bignay and is a found in several Asian countries. This plant is famous in South Asia. In the traditional medicine, various plant parts such as root, bark, leaves, fruits which are used in traditional system of medicine for a long time, for the treatment of various disease due to having cytotoxic, anti-diabetic, antioxidant, antiradical, thrombolytic activity, antiplatelet, anticoagulant, anti-dysenteric, antimicrobial, antihypertensive, anticancer and sudorific activity. This plant can also be used as pesticide agents. This plant also has a role in improvement of blood circulation. It is a good remedy for snakebite, coughs, flatulence and intestinal colic. Phytochemical analysis of the Antidesma bunius has confirmed presence of different kinds of flavonoids, terpene, sugar, saponin, tannin, toxic alkaloids, phenolic acids, procyanidin B1, procyanidin B2 and anthocyanins. This present study gives an insight to the pharmacogonstical, phytochemical and pharmacological properties of Antidesma bunius.
\end{abstract}

Keywords: Antidesma bunius Linn, euphorbiaceae, phytochemical, pharmacological activity
Volume 7 Issue 5 - 2018

\author{
Md. Shariful Islam,' Md. Sharif Ahammed, \\ Fakhrul Islam Sukorno,' Sabiha Ferdowsy \\ Koly,' Md. Morad Biswas,' Shaikat Hossain \\ 'Department of Pharmacy, Southeast University, Bangladesh \\ 2Department of Pharmacy, North south University, Bangladesh
}

Correspondence: Md. Shariful Islam, Department of Pharmacy, Southeast University, Banani, Dhaka-1213, Bangladesh, Tel 01685945797,Email sharif.sew17@gmail.com

Received: September 28, 2018 | Published: October 24, 2018

\section{Introduction}

Antidesma bunius is a genus of about 150 species distributed in Asia, Africa, Australia and Islands of pacific. ${ }^{1}$ Antidesma bunius (Family- Euphorbiaceae), also known as bignai in the Philippines; buni or berunai in Malaya (India); wooni or hooni, in Indonesia; ma mao luang in Thailand; kho lien tu in Laos; choi moi in Vietnam; moi-kin and chunka by the aborigines in Queensland. The English names are Chinese laurel, currant tree, nigger's cord, and salamander tree which is a native of India and other countries like Nepal, Myanmar, Singapore, Sri Lanka, Pakistan, and Bangladesh. Antidesma bunius has various synonyms like Stilago bunius L., Antidesma rumphii Tulasne, Antidesma dallachyanum Baillon. Antidesma bunius has various common names bignay, Chinese laurel, blackcurrant tree, salamander tree, antidesme, antidesma da China, cardoeira, buni, wuni, huni, bunch, paginga, isip, kho liên tu, baa mao ruesee, mamao dong, mao chaang, chiòi mòi. ${ }^{2}$ The Antidesma bunius is common medicinal plants in many dipterocarp forests in Thailand and widespread in the Philippines. ${ }^{3}$ There claims that the plant is common in the wild from the lower Himalayas in India, Ceylon and Southeast Asia and northern Australia. The plant is also grown in Indonesia, and cultivated in Malaya. ${ }^{2}$ The fresh fruit wine has considerably antioxidant properties. ${ }^{4}$ Wine has considerably been associated with chemo protection and cardio protection than other alcoholic beverage,$^{5}$ it was hypothesized that some phenolic compounds in red wine which such as polyphenols, flavonoids and anthrocyanins play an important role in the prevention of coronary heart diseases. ${ }^{4}$ On the other hand, A. bunius contains lactic acid, acetic acid, caffeic acid and ascorbic acid have also shown a positive effect on type 2 diabetes. ${ }^{3,6}$ Roots and leaves extract have antihelminthic property and also used in the treatment of indigestion cough and stomach ache. The seeds are commonly employed as antihelminthic and said to be effective against round worms and threadworms. The barks extracts are used as antitoxins which are used in tribal areas as human herbal medication. They are also given in coughs, flatulence, intestinal colic. It is also used as pesticide. Antidesma bunius is traditionally used as sudorific and in the treatment of snakebite; decoction is used to promote perspiration in febrile condition; fruit juice of the plant is useful in the treatment of insomnia. ${ }^{2}$

\section{Habit and habitat}

Antidesma bunius plant grows all over Bangladesh in many wet evergreen forest, dipterocarp forest, teak forest; at forest edges, on river bank, roadsides, in bamboo thickets; in semi-cultivated and cultivated areas. The tree growing to $6 \mathrm{~m}$ tall but can reach $15-30 \mathrm{~m}$ high. The rich green leafage provides a good shade and the bark is reddish grey $^{2}$ (Figure 1).

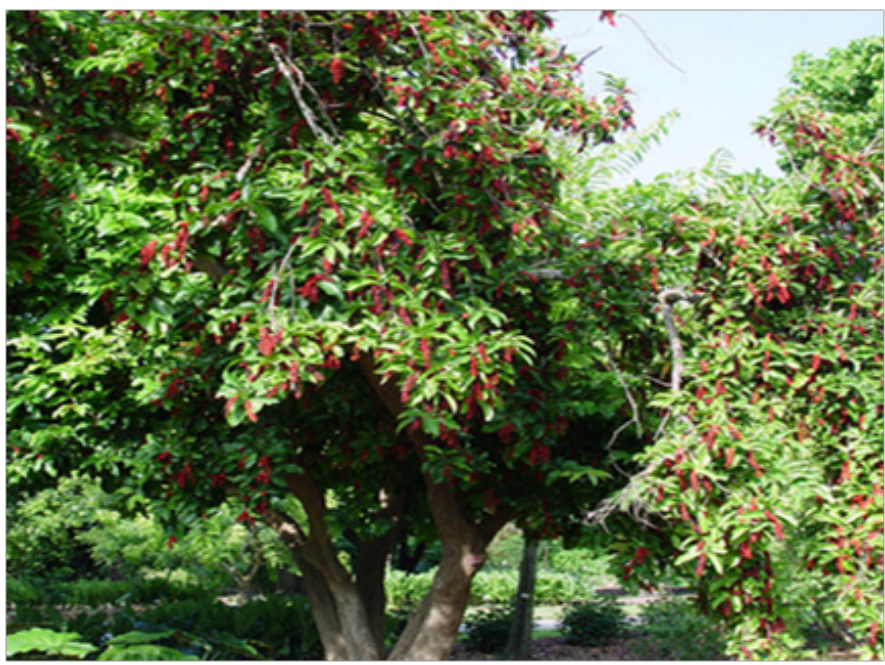

Figure I Fruits, leaves, trunk of Antidesma bunius. 


\section{Pharmacognostical characteristics}

\section{Macroscopical (Plant description)}

The Antidesma bunius is native species in the Philippines and is also common in the wild from the lower Himalayas in India, Ceylon, and Southeast Asia to Northern Australia but this plant occasionally cultivated in Malaya, grown in every village in Indonesia where the fruits are marketed in clusters. This plant may be shrubby, growing up to $6 \mathrm{~m}$ tall, or may reach up to $15-30 \mathrm{~m}$ high. The leaves are oblong; 4 to 9 inches $(10-22.5 \mathrm{~cm})$ long, 2 to 3 in $(5-7.5 \mathrm{~cm})$. The fruits is ovoid fleshy, up to $1 / 3$ in $(8 \mathrm{~mm})$ across, its color from green to pale yellow. The unripe fruits are very acidic and sweet when fully ripe. It has a sour sweet-bitter taste and red to blackish color as it ripens. ${ }^{7}$ Which is a single straw-colored stone, an irregular, flattened oval, ridged or fluted, very hard, $3 / 8$ in $(1 \mathrm{~cm})$ long, $1 / 4$ in $(6 \mathrm{~mm})$ wide. ${ }^{4}$ A $100 \mathrm{~g}$ of the edible portion of $A$. bunius contains water $90-95 \mathrm{~g}$, carbohydrates $6.3 \mathrm{~g}$, fat $0.8 \mathrm{~g}$, protein $0.7 \mathrm{~g}$, calcium $37-120 \mathrm{mg}$, phosphorus $22-40 \mathrm{mg}$, vitamin C $8 \mathrm{mg}$, vitamin A $10 \mathrm{IU}$, iron $0.1-0.7 \mathrm{mg}$. The energy value is $134 \mathrm{~kJ} / 100 \mathrm{~g}$. Citric acid is the predominant organic acid. ${ }^{7}$

\section{Taxonomy}

Kingdom: Plantae

Phylum: Tracheophyta

Class: Magnoliopsida

Order: Euphorbiales

Family: Euphorbiaceae

Genus: Antidesma

Species: A. bunius

Scientific name: Antidesma bunius

\section{Active principles}

Antidesma bunius (Linn) leaves, fruits, roots and bark contains many various polyphenols namely terpen, sugar, saponin, tannin, biflavonoid, anthocyanin, luteolin, rutin, resveratrol, quercetin, procyanidin, catechins, amentoflavone, corilagin (1-O-galloyl 3,6-O-hexahydroxydiphenoyl-ßglucopyranoside), gallic acid (3, 4, 5-trihydroxybenzoic), ferrulic acid, ellagic acid, catechin, procyanidin, vicinin II (Apigenin-6, 8-di-C- $\beta$-D-glucopyranoside), tartaric acid, citric acid, benzoic acid, malic acid, lactic acid, oxalic acid, acetic acid and ascorbic acid, caffeic acid. ${ }^{3,8,9}$

\section{Traditional uses}

Antidesma bunius Linn has been widely used in traditional medicine for a widespread range of diseases. Its leaves, fruits, bark, roots and seeds are used in different forms. ${ }^{10}$

Leaves: The leaves are used as a traditional medicine for the treatment of skin disorder, syphilis and snakebites. It is also effectively used in indigestion, cough, stomachache, hepatoprotective and hepatotoxicity activities of $A$. bunius leaves. ${ }^{11-13}$

Fruits: The Fruits are healthy alcoholic juice drink and cooked with fish or other foods. A. bunius fruits contain anti-toxins which are traditionally used in the management of diabetes, hypertension, gastric intestinal problems, dysentery, indigestion, constipation, remedies for animals like sheep and goats. ${ }^{7,10,14}$
Roots: Roots are used as antihelminthic and also recommended in cough and stomachache and indigestion. ${ }^{12}$

Bark: The bark of $A$. bunius Linn is traditionally used the bark for diabetic agent in Asia. ${ }^{15}$

Seeds: A. bunius Linn seeds are traditionally used as anthelmintic against round worms and thread worms. They are also useful in cough, flatulence, intestinal colic management. The seeds are also used recommended as pesticide agent. ${ }^{11,12}$

\section{Pharmacological activities}

\section{Cytotoxic activity}

The methanolic extract of leaves and fruits of Antidesma bunius was carried out to analyze its biological activity using the brine shrimp hatchability and lethality assay. Higher activity was observed in fruit extract and it was comparable to the positive control used. It is possible that Antidesma bunius contains compounds with potential cytotoxic activity. ${ }^{12,17}$

\section{Hypoglycemic activity}

An experiment was carried out to analyze $\alpha$-Glucosidase inhibitory activity of Antidesma bunius used to control diabetes. From that experiment this plant was screened for their potential $\alpha$-glucosidase inhibitory activity and the result was positive. ${ }^{17}$

They carried out an experiment on methanolic extract of Antidesma bunius stem, barks and leaves to evaluate $\alpha$-glucosidase inhibitory activity. Methanolic extraction of leaves showed the highest $\alpha$-glucosidase inhibitory activity. They also carried out phytochemical analysis of ethyl acetate extract of Antidesma bunius stem, barks displayed the presence of sugars, terpenes, and flavonoids, while methanolic extract of Antidesma bunius leaves contains sugars, saponins, flavonoids, and tannins. ${ }^{18}$

An Experiment carried out to investigate hypoglycaemic activities of methanolic extract of Antidesma bunius in type 1 diabetes. The results suggested that Antidesma bunius extract possess anti-diabetic activity, through the enhancement of hepatic glycogen storage and regeneration of the islet of Langerhans. ${ }^{19}$

Diabetes is increasing day by day globally. Several herbal medicines have been studied and some are proven to have a beneficial effect against it. Some from the group of organic acids, phenolic acids and flavonoids contribute to the decreasing effect of hyperglycemia. From this experiment they saw that Antidesma bunius showed an evidence of having the said contents. ${ }^{20}$

\section{Antiradical activity}

Studies was done on the influence of methanolic, total phenolic, total anthocyanin extract of Antidesma bunius on the changes in physico-chemical properties, antiradical activity Antidesma bunius fruits in the period of development and ripening. The Therapeutic property gradually decreased from the immature to the over ripe stages. The total anthocyanin content (TA) showed the highest content at the over ripe stage. The antiradical activity (AA) of methanolic extracts from Antidesma bunius fruits during development and ripening were determined with DPPH (2,2-diphenyl-1-picrylhydrazyl) radical scavenging. The highest $\mathrm{AA}$ was observed at the immature stage. The level of procyanidin $\mathrm{B} 2$, procyanidin $\mathrm{B} 1,(+)$-catechin, (-)-epicatechin, rutin and tran-resveratrol as the main polyphenol 
compounds, increase during fruit development and ripening. Other phenolic acids such as gallic, caffeic, and ellagic acids significantly decreased during fruit development and ripening. At over ripe stage Antidesma bunius possess the highest antioxidants. ${ }^{21}$

\section{Pesticide activity}

A study was carried out to analyze the potential of Antidesma bunius fruit extract as an organic pesticide against the Epilachna spp., of the family Coccinellidae. Antidesma bunius fruit crude extracts of $50 \%, 75 \%$ and $100 \%$ were used. A commercial pesticide was used as positive control and water as negative control. The commercial pesticide registered an average MTL of $10 \mathrm{~min}$ while majority of those treated with pure fruit extract registered a 15 min MTL. Phytochemical analysis of the fruit extract showed the presence of flavonoids and phenols that might contribute to its pesticide property. Results of this study indicate that $A$. bunius fruit extract can serve as a novel alternative source of organic pesticide and that the pure crude fruit extract was proven effective against the Epilachna spp. ${ }^{22}$

\section{Antioxidant activity}

The fruits of $A$. bunius were evaluated for its antioxidant activity which revealed a positive antioxidant property. After having the result they got a good amount of antioxidant properties from the experiment of Antidesma bunius. ${ }^{23}$

\section{Conclusion}

A. bunius is the traditional system of medicine and with multiple pharmacological actions. In this review, included the traditional use, phytochemistry and pharmacology in a illustrative manner. The extracts and phytoconstituents isolated from this plant have been shown to produce various pharmacological response, which include cytotoxic, anti-diabetic, antioxidant, antiradical, thrombolytic activity, antiplatelet, anticoagulant, anti-dysenteric, antimicrobial, antihypertensive, anticancer, sudorific activity and improvement of blood circulation. The multiple traditional uses and pharmacological responses of $A$. bunius authorized us to write this review article. This review will provide all the scientific knowledge in a summary manner to the scientific society.

\section{Acknowledgements}

None.

\section{Conflict of interest}

The author declares that there is no conflict of interest.

\section{References}

1. Hans AS. Polyploidy in Antidesma (Euphorbiaceae). Caryologia. 1970;23(3):321-327.

2. J Morton. Bignay. In: Fruits of warm climates. In: Julia F Morton, editor. Miami: USA; 1987:210-212.

3. Butkhup L, Samappito S. An analysis on flavonoids contents in Mao Luang fruits of fifteen cultivars (Antidesma bunius), grown in northeast Thailand. Pakistan journal of biological sciences. 2008;11(7):996-1002.

4. Belina-Aldemita MD, Sabularse VC, Dizon EI, et al. Antioxidant properties of bignay [Antidesma bunius (L.) Spreng.] wine at different stages of processing. The Philippine Agricultural Scientist. 2013;96(3).

5. Rimm EB, Klatsky A, Grobbee D, et al. Review of moderate alcohol consumption and reduced risk of coronary heart disease: is the effect due to beer, wine, or spirits. BMJ. 1996;312(7033):731-736.
6. Hay ID, Thompson GB, Grant CS, et al. Papillary thyroid carcinoma managed at the Mayo Clinic during six decades (1940-1999): temporal trends in initial therapy and long-term outcome in 2444 consecutively treated patients. World J Surg. 2002;26(8):879-885.

7. Belmi RM, Giron J, Tansengco ML. Antidesma bunius (bignay) fruit extract as an organic pesticide against Epilachna spp. Journal of Asian Scientific Research. 2014;4(7):320.

8. Kassem ME, Hashim AN, Hassanein HM. Bioactivity of Antidesma bunius leaves (Euphorbiaceae) and their major phenolic constituents. European Scientific Journal. 2013;9(18).

9. TK Lim. Edible medicinal and non-medicinal plants fruits. New York: Springer; 2012.

10. Butkhup L, Samappito S. An analysis on flavonoids contents in Mao Luang fruits of fifteen cultivars (Antidesma bunius), grown in northeast Thailand. Pakistan journal of biological sciences. 2008;11(7):996-1002.

11. Lim TK. Antidesma bunius. In Edible Medicinal and Non-Medicinal Plants. Netherlands: Springer; 2012; 220-224 p.

12. Zaman S, Islam MS, Koly SF, et al. Evaluation of Cytotoxicity and Antibacterial Activities of Methanolic Extract of Antidesma bunius (Linn.)(Family Euphorbiaceae) Leaf. Journal of Advances in Medical and Pharmaceutical Sciences. 2018;16(2):1-7.

13. Sosef MSM, Prawirohatmodjo S, Hong LT. Timber trees: lesser known species. Plant resources of south east Asia. Backhuys Publishers: Asia; 1998. p 859.

14. Khomdram S, Arambam S, Barthakur S, et al. Biochemical, Nutritional Profiling and Optimization of an Efficient Nucleic Acid Isolation Protocol from Recalcitrant Tissue of Wild Edible Fruit Antidesma bunius L. Spreng. Int J Curr Microbiol App Sci. 2017;6(4):253-64.

15. Mauldina MG, Sauriasari R, Elya B. $\alpha$-Glucosidase inhibitory activity from ethyl acetate extract of Antidesma bunius (L.) Spreng stem bark containing triterpenoids. Pharmacogn Mag. 2017;13(52):590.

16. Jose Rene L Micor, Custer C Deocaris, Elmer-Rico E Mojica. Biological Activity of Bignay [Antidesma bunius (L.) Spreng] Crude Extract in Artemiasalina. Journal of Medical Sciences. 2005;5(3):195-198.

17. Lawag IL, Aguinaldo AM, Naheed S, et al. $\alpha$-Glucosidase inhibitory activity of selected Philippine plants. Journal of ethnopharmacology. 2012;144(1):217-219.

18. Elya B, Malik A, Mahanani PI, et al. Antidiabetic activity test by inhibition of $\alpha$ Glucosidase and phytochemical screening from the most active fraction of Buni(Antidesma bunius L.) stem barks and leaves. International Journal of Pharma Tech Research. 2012;4(4):1667-1671.

19. El-Tantawy WH, Soliman ND, El-Naggar D, et al. Investigation of antidiabetic action of Antidesma bunius extract in type 1 diabetes. Archives of physiology and biochemistry. 2015;121(3):116-122.

20. S Herrera, A Panopio, H Pedrezuela, et al. Antiglycemic Effect of Bignay (Antidesma bunius) Flavonoids in Sprague-Dawley Rats.

21. L Butkhup, S Samappito. Chemical properties, polyphenol compounds and antiradical activity during development and ripening of maoluang (Antidesma Bunius L. Spreng) fruits. Journal of Fruit and Ornamental Plant Research. 2011.

22. RM Belmi, J Giron. Antidesma Bunius (Bignay) Fruit Extract as an Organic Pesticide Against Epilachna Spp. Journal of Asian Scientific. 2014.

23. MD Belina-Aldemita, VC Sabularse. Antioxidant properties of bignay [Antidesma bunius (L.) Spreng.] wine at different stages of processing. The Philippine. 2013. 